\title{
PENINGKATAN MUTU MI KERING JAGUNG DENGAN PENERAPAN KONDISI OPTIMUM PROSES DAN PENAMBAHAN MONOGLISERIDA
}

\author{
[Quality Improvement of Dried Corn Noodle through the Optimization of Processing Conditions and \\ Addition of Monoglyceride]
}

\author{
Subarna*, Tjahja Muhandri, Budi Nurtama dan Antung Sima Firlieyanti \\ Departemen IImu dan Teknologi Pangan, Fakultas Teknologi Pertanian, Institut Pertanian Bogor, Bogor
}

Diterima 08 November 2011 / Disetujui 08 Mei 2012

\begin{abstract}
The objective of this research was to improve the quality of dried corn noodle through the optimization of processing condition using a cookingforming extruder and the addition of monoglyceride. The process conditions was optimized using Response Surface Methodology (RSM) based on two processing parameters i.e., extruder temperatures $\left(80-90^{\circ} \mathrm{C}\right)$ and screw speeds $(75-125 \mathrm{rpm})$. The optimum condition of cooking extrusion was obtained at $90^{\circ} \mathrm{C}$ and $75 \mathrm{rpm}$. However, the noodle firmness and stickiness were unsatisfactory. The use of $1 \%$ Glyseryl Mono Stearate significantly improved the quality of the noodle with acceptable firmness, elasticity, and elongation. However, the cooking loss and stickiness were still high.
\end{abstract}

Keywords: dried corn noodle, Glyseryl Mono Stearate, noodle quality, preference test, Response Surface Methodology

\begin{abstract}
ABSTRAK
Penelitian bertujuan untuk meningkatkan mutu mi kering jagung melalui optimasi proses menggunakan ekstruder pemasak-pencetak dan penambahan monogliserida. Optimasi proses dilakukan menggunakan Response Surface Methodology (RSM) dengan dua variabel proses yaitu suhu ekstruder $\left(80-90^{\circ} \mathrm{C}\right)$ dan kecepatan ulir ekstruder $(75-125 \mathrm{rpm})$. Kondisi proses optimum diperoleh pada suhu $90^{\circ} \mathrm{C}$ dan kecepatan ulir 75 rpm. Mutu kekerasan dan kelengketan mi belum memuaskan. Penggunaan 1\% Gliseril Mono Stearat dapat meningkatkan penerimaan mutu kekerasan, elastisitas dan elongasi mi secara signifikan. Kelemahan yang muncul adalah cooking loss dan kelengketan mi masih tinggi.
\end{abstract}

Kata kunci: mi kering jagung, Gliseril Mono Stearat, mutu mi, uji penerimaan, Response Surface Methodology

\section{PENDAHULUAN}

Pengembangan produk mi berbahan baku tepung nonterigu telah dilakukan oleh beberapa peneliti. Teknologi yang banyak digunakan adalah teknologi ekstrusi, baik menggunakan ekstruder pencetak maupun ekstruder pemasak-pencetak.

Produk-produk yang diteliti diantaranya adalah mi kering dari tepung jagung menggunakan ekstruder pencetak (Waniska et al., 1999), mi basah dari tepung jagung menggunakan ekstruder pemasak-pencetak (Muhandri et al., 2011) dan vermicelli kering dari tepung beras menggunakan ekstruder pemasak-pencetak (Charutigon et al., 2008). Produk lain yang mirip adalah makaroni kering dari tepung beras dengan ekstruder pemasak-pencetak (Marti et al., 2010).

Mi kering yang dihasilkan dari ekstruder pencetak memiliki cooking loss yang tinggi yaitu $>47 \%$ (Waniska et al., 1999). Produk dari proses ekstruder pemasak-pencetak memiliki cooking loss yang rendah yaitu 4,20\% (Marti et al., 2010), $7,10 \%$ (Charutigon et al., 2008) dan 4,56\% (Muhandri et al., 2011).

*Korespondensi Penulis :

E-mail : tpg@ipb.ac.id/cahyomuhandri@yahoo.com; Hp: 0812-8426230
Produk yang dihasilkan dari proses menggunakan ekstruder pemasak-pencetak memiliki mutu yang lebih bagus dibandingkan dengan ekstruder pencetak. Marti et al. (2010) menyatakan bahwa produk makaroni dari tepung beras yang diproses dengan ekstruder pemasak-pencetak memiliki cooking loss sebesar $4,2 \%$, jauh lebih rendah dibandingkan dengan cooking loss pasta yang dibuat dengan ekstruder pencetak (ekstruder pasta) yaitu $15,9 \%$. Hal ini disebabkan oleh kecukupan proses gelatinisasi dan shear stress.

Hasil penelitian mi jagung sebelumnya yang menggunakan ekstruder pemasak-pencetak (Muhandri et al., 2011) menghasilkan mi dengan kekerasan tinggi dan sulit diterima oleh panelis, walau elongasinya tinggi dan cooking loss-nya rendah. Hal ini karena ukuran mi jagung yang dihasilkan terlalu besar sebagai akibat dari die ekstruder yang besar $(2,5 \mathrm{~mm})$. Menurut Charutigon et al. (2008), kekerasan vermicelli dipengaruhi oleh mekanisme gelatinisasi dan retrogradasi tepung atau pati. Lebih lanjut Charutigon et al. (2008) mengatakan bahwa penambahan monogliserida mampu menurunkan tingkat retrogradasi tepung, sehingga menurunkan kekerasan vermicelli.

Penelitian ini bertujuan untukmenentukan kondisi optimum proses pembuatan mi kering jagung menggunakan ekstruder pemasak-pencetak ulir tunggal (single screw extruder) dengan 
Response Surface Methodology (RSM) pada penggunaan eliptical die. Selain itu, studi ini dilakukan untuk mengetahui pengaruh penambahan monogliserida terhadap mutu mi jagung, dan mengevaluasi tingkat penerimaan konsumen terhadap mi kering jagung.

\section{BAHAN DAN METODE}

\section{Bahan}

Bahan utama yang digunakan dalam penelitian ini adalah jagung pipil varietas P21 yang diperoleh dari Dinas Pertanian Kab. Ponorogo, $\mathrm{Ca}(\mathrm{OH})_{2}$, GMS (Gliseril Mono Stearat), $\mathrm{NaCl}$, dan air.

\section{Penyiapan tepung jagung}

Proses penepungan dilakukan dengan teknik penepungan kering. Teknik penepungan ini terdiri atas dua tahap proses, yaitu proses penggilingan kasar (pin disc mill saringan 10 mesh), pencucian dan pengambangan, perendaman grits, pengeringan grits; dan penggilingan halus (pin disc mill saringan 48 mesh), pengeringan tepung, pengayakan tepung ukuran 100 mesh, dan pengeringan tepung setelah tepung diayak.

\section{Proses pembuatan mi kering}

Proses pembuatan mi dilakukan dengan tahapan pencampuran tepung dengan air $(80 \% \mathrm{bb})$ dan garam $(2 \% \mathrm{bb})$ menggunakan hand mixer selama 5 menit, adonan dimasukkan ke dalam ekstruder kemudian mi dikeringkan. Ekstruder yang digunakan adalah ekstruder pemasak-pencetak ulir tunggal dengan ukuran eliptical die yang berukuran $1 \mathrm{~mm}$ diameter pendek dan 1,5 mm diameter panjang. Pengeringan mi jagung dilakukan dengan dua cara, yaitu menggunakan fluid bed drier dengan suhu pengeringan $50^{\circ} \mathrm{C}$ dan pengeringan dengan membiarkan mi berada pada kondisi ruang selama 1 jam kemudian dilanjutkan dengan pengering hembus (tanpa pemberian panas) selama 3 jam.

\section{Optimasi proses pembuatan mi dan penambahan GMS}

Pada penelitian ini optimasi proses menggunakan teknik RSM dengan rancangan D-Optimal Design model kuadratik. Variabel yang digunakan adalah suhu ekstruder $\left(80,85,90^{\circ} \mathrm{C}\right)$ dan kecepatan ulir ekstruder $(75,100,125 \mathrm{rpm})$. Respon mutu mi kering jagung yang diukur adalah cooking loss, elongasi, dan profil tekstur (ketegaran, kekenyalan dan kelengketan). Program Design Expert versi 7 digunakan untuk mendesain dan mengolah data yang diperoleh.

Proses optimum ditetapkan berdasarkan constraint ketegaran dan cooking loss minimum, sedangkan elongasi, kekenyalan dan kelengketan adalah in range. Setelah diperoleh kondisi optimum, penelitian dilanjutkan untuk melihat pengaruh penambahan GMS pada empat tingkat konsentrasi yaitu 0, 1, 1,5 dan $2 \%$. Data yang diperoleh dianalisis keragamannya dengan Uji ANOVA dan uji lanjut Duncan menggunakan program statistik SPSS 17.

\section{Analisis karakteristik fisik mi kering jagung}

Analisis fisik mi jagung meliputi analisis cooking loss, elongasi, dan profil tekstur (ketegaran, kekenyalan dan kelengketan) menggunakan Texture Analyzer TA-XT2i. Mi jagung yang dianalisis adalah mi kering yang telah direhidrasi. Rehidrasi dilakukan dengan perebusan selama 8 menit berdasarkan hasil uji coba kecukupan proses pemasakan mi kering jagung.

\section{Pengukuran cooking loss}

Penentuan cooking loss dilakukan dengan cara merebus sekitar $5 \mathrm{~g}$ mi dalam $150 \mathrm{ml}$ air selama 3 menit lalu mi ditiriskan. Kemudian, mi dikeringkan pada suhu $100^{\circ} \mathrm{C}$ hingga beratnya konstan, lalu ditimbang kembali. Mi yang lain sebanyak kira-kira $5 \mathrm{~g}$ diukur kadar airnya (data kadar air digunakan untuk menghitung berat kering sampel). Cooking loss (CL) dihitung dengan rumus berikut:

$$
C L=\frac{a-b}{a} \times 100 \%
$$

Keterangan: $a=$ Berat kering sampel sebelum direbus; $b=$ Berat kering sampel sesudah direbus

\section{Analisis persen elongasi menggunakan texture analyzer TA-XT2i}

Sampel dililitkan pada probe dengan jarak probe sebesar 2 $\mathrm{cm}$ dan kecepatan probe $0,3 \mathrm{~cm} / \mathrm{s}$. Persen elongasi dihitung dengan rumus :

$$
\text { Elongasi }(\%)=\frac{\text { WaktuPutus Sampel }(\mathrm{s}) \times 0,3 \mathrm{~cm} / \mathrm{s}}{2 \mathrm{~cm}} \times 100 \%
$$

Analisis profil tekstur menggunakan texture analyzer TAXT2i

Probe yang digunakan berbentuk silinder dengan diameter $35 \mathrm{~mm}$. Pengaturan TAXT-2 yang digunakan adalah sebagai berikut: pre-test speed $2,0 \mathrm{~mm} / \mathrm{s}$, test speed $0,1 \mathrm{~mm} / \mathrm{s}$, rupture test distance $75 \%$, mode measure force in compression dan force $100 \mathrm{~g}$.

Seuntai sampel dengan panjang yang melebihi diameter probe diletakkan di atas landasan lalu ditekan oleh probe. Hasilnya berupa kurva yang menunjukkan hubungan antara gaya yang diperlukan untuk kompresi dan waktu. Nilai kekerasan ditunjukkan dengan absolute $(+)$ peak, dan nilai kelengketan ditunjukkan dengan absolute(-) peak. Satuan kedua parameter ini adalah gramforce $(g F)$. Profil tekstur mi dapat dilihat dengan membandingkan kemiringan kurva yang dihasilkan. Kurva yang landai menunjukkan bahwa mi relatif kompresibel, sedangkan kurva yang curam menunjukkan bahwa mi relatif kaku.

\section{Analisis preferensi konsumen}

Pengujian organoleptik yang dilakukan adalah uji preferensi dengan 30 orang panelis. Uji ini digunakan untuk melihat tingkat penerimaan konsumen terhadap mi yang dihasilkan, dengan skor 1-5 (sangat tidak suka-sangat suka). Sampel disiapkan dengan cara merebus mi selama 8 menit, kemudian ditiriskan selama 2 menit. Selanjutnya, diambil 6 untai mi dengan panjang 
yang sama dan diletakkan diatas piring penyajian untuk dinilai atribut elongasi, ketegaran (kekerasan), kekenyalan dan penampakan umum oleh panelis.

\section{HASIL DAN PEMBAHASAN}

Optimasi proses pembuatan mi kering jagung dengan RSM

Berdasarkan teknik RSM dengan rancangan D-Optimal Combine, desain model kuadratik, dari dua variabel dengan tiga taraf perlakuan, diperoleh 12 satuan percobaan. Kombinasi variabel suhu ekstruder dan kecepatan ulir dengan hasil pengukuran datalima parameter proses pembuatan mi, disajikan pada Tabel 1.

Tabel 1. Hasil pengukuran mi pada proses optimasi menggunakan

\begin{tabular}{ccccccc}
\multicolumn{7}{c}{ RSM } \\
$\begin{array}{c}\text { Suhu } \\
\text { Ekstruder } \\
\left({ }^{\circ} \mathrm{C}\right)\end{array}$ & $\begin{array}{c}\text { Kec. } \\
\text { Ulir } \\
(\mathrm{rpm})\end{array}$ & $\begin{array}{c}\text { Cooking } \\
\text { Loss } \\
(\%)\end{array}$ & $\begin{array}{c}\text { Elongasi } \\
(\%)\end{array}$ & $\begin{array}{c}\text { Ketegaran } \\
(\mathrm{gf})\end{array}$ & $\begin{array}{c}\text { Kemem- } \\
\text { balan } \\
(\%)\end{array}$ & $\begin{array}{c}\text { Keleng- } \\
\text { ketan }(\mathrm{gf})\end{array}$ \\
\hline 90 & 75 & 5,47 & 112,36 & 6872,2 & 60,43 & 56,1 \\
90 & 125 & 5,31 & 105,46 & 11589,8 & 54,23 & 45,5 \\
85 & 125 & 5,73 & 108,42 & 10116,3 & 44,36 & 53,9 \\
80 & 100 & 12,42 & 34,53 & 4023,4 & 39,43 & 310,8 \\
90 & 100 & 4,34 & 87,84 & 5951,5 & 59,00 & 41,3 \\
85 & 75 & 6,43 & 107,35 & 5250,2 & 42,32 & 136,9 \\
80 & 75 & 13,46 & 42,20 & 3207,2 & 38,04 & 446,8 \\
80 & 125 & 11,74 & 37,55 & 4223,1 & 38,33 & 542,1 \\
85 & 100 & 6,88 & 98,41 & 8548,7 & 48,69 & 81,0 \\
90 & 75 & 4,31 & 135,46 & 6275,0 & 48,98 & 78,5 \\
80 & 75 & 10,86 & 52,78 & 3421,2 & 37,43 & 467,5 \\
80 & 125 & 12,10 & 36,64 & 3865,8 & 35,55 & 521,3 \\
\hline
\end{tabular}

Pada awal percobaan, pengeringan mi jagung dilakukan dengan menggunakan fluid bed drier (pengeringan dengan hembusan udara), pada suhu pengeringan $50^{\circ} \mathrm{C}$. Metode pengeringan menghasilkan mi kering jagung yang bersifat retak retak dan ketika direhidrasi, mi jagung menjadi patah-patah dalam potongan yang berukuran panjang sekitar $2 \mathrm{~cm}$ (Gambar 1). Menurut Charutigon et al. (2008) pengeringan vermicelli beras dilakukan dengan cara kering angin selama 24 jam.

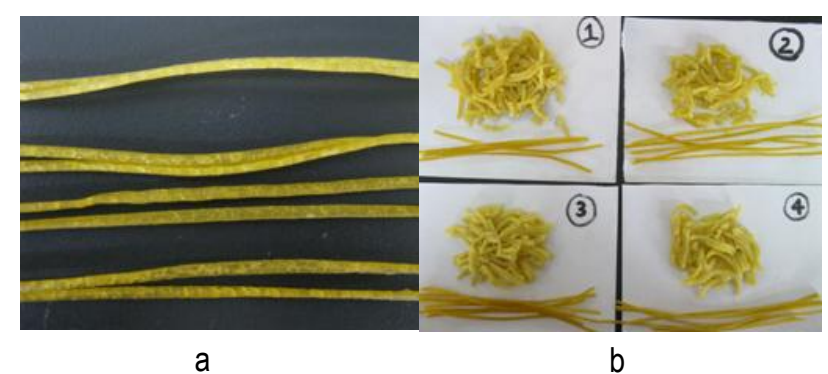

Gambar 1. Mi kering jagung dengan pengeringan suhu $50^{\circ} \mathrm{C}$ (a) sebelum rehidrasi dan (b) sesudah rehidrasi

Inazu et al. (2002) menyatakan bahwa pada pengeringan mi jepang (udon), pengeringan awal mi dilakukan pada suhu rendah $\left(15-20^{\circ} \mathrm{C}\right)$, pengeringan utama dilakukan pada $\mathrm{RH}$ tinggi $(70-80 \%)$ pada suhu $30-35^{\circ} \mathrm{C}$ dan pengeringan akhir dilakukan sampai kadar air $14 \%$ dengan menurunkan suhu secara bertahap. Dengan metode tersebut bisa mencegah mi keriput dan retak-retak proses pengeringan mi jagung pada tahap penelitian selanjutnya dilakukan dengan membiarkan mi berada pada kondisi ruang selama 1 jam kemudian dikeringkan dengan pengering hembus (tanpa pemberian panas) selama 3 jam. Produk akhir mi kering jagung memiliki kadar air antara 9-13\%. Rekapitulasi hasil analisis untuk semua respon terukur disajikan pada Tabel 2. Nilai $\mathrm{R}^{2}$ untuk semua respon cukup tinggi yaitu di atas 0,80. Menurut Henika (1982), pada metode RSM dengan nilai $\mathrm{R}^{2}$ diatas 0,75 dianggap cukup baik untuk menyusun model.

Tabel 2. Rekapitulasi hasil analisa regresi untuk respon terukur pada optimasi pembuatan mi kering

\begin{tabular}{|c|c|c|c|c|c|}
\hline Parameter & $\begin{array}{l}\text { Cooking } \\
\text { Loss (\%) }\end{array}$ & $\begin{array}{c}\text { Elongasi } \\
(\%)\end{array}$ & $\begin{array}{c}\text { Ketegaran } \\
\text { (gf) }\end{array}$ & $\begin{array}{c}\text { Kemem- } \\
\text { balan (\%) }\end{array}$ & $\begin{array}{c}\text { Keleng- } \\
\text { ketan }(\mathrm{gf})\end{array}$ \\
\hline $\begin{array}{c}\text { Prediksi } \\
\text { model }\end{array}$ & Kuadratik & Kuadratik & Kuadratik & Linier & Kuadratik \\
\hline $\begin{array}{l}\text { Signifikansi } \\
\text { model }\end{array}$ & $0,0004^{* * *}$ & $0,0004^{* \star *}$ & $0.0075^{\star \star}$ & $0.0001^{* * *}$ & $0.0005^{* \star \star}$ \\
\hline $\mathrm{X}_{1}$ (suhu) & $<0,0001^{\star \star *}$ & $<0,0001^{* * *}$ & $0.0015^{\star *}$ & $<0.0001^{\star \star *}$ & $<0.0001^{* \star *}$ \\
\hline $\begin{array}{l}\mathrm{X}_{2} \\
\text { (kecepatan } \\
\text { ulir) }\end{array}$ & 0,8135 & 0,1396 & $0.0092^{* *}$ & 0,9645 & 0,9076 \\
\hline$X_{1}{ }^{2}$ & $0,0140^{*}$ & $0,0032^{* *}$ & 0,0503 & & $0,0074^{* *}$ \\
\hline $\mathrm{X}_{2}{ }^{2}$ & 0,08304 & 0,0684 & 0,4378 & & 0,1058 \\
\hline$X_{1} X_{2}$ & 0,7762 & 0,5924 & 0,0792 & & 0,3335 \\
\hline $\mathrm{R}^{2}$ & 0,9618 & 0,9595 & 0,8910 & 0,8596 & 0,9576 \\
\hline
\end{tabular}

Keterangan: * signifikan pada taraf $0,05,{ }^{* *}$ signifikan pada taraf $0,01,{ }^{* \star *}$ signifikan pada taraf 0,001

Cooking loss menunjukkan banyaknya padatan dalam mi yang keluar ke dalam air selama proses pemasakan. Cooking loss merupakan salah satu parameter mutu yang penting karena berkaitan dengan kualitas mi setelah dimasak. Nilai cooking loss yang diinginkan adalah yang relatif kecil. Semakin rendah nilai cooking loss menunjukkan bahwa mi tersebut memiliki tekstur yang baik dan homogen. Berdasarkan hasil analisis keragaman (Tabel 2), peningkatan suhu ekstruder berpengaruh nyata terhadap cooking loss mi kering jagung $(p<0,05)$. Kecepatan ulir ekstruder tidak berpengaruh nyata terhadap cooking loss mi kering jagung $(p>0,05)$. Visualisasi model disajikan pada Gambar 2.

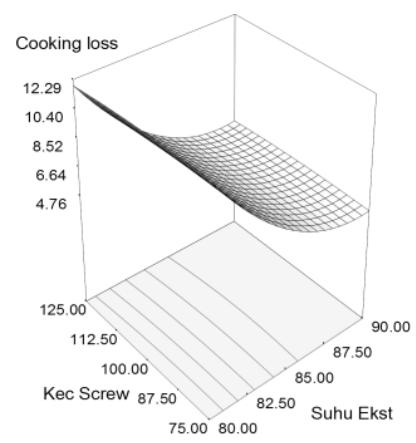

Gambar 2. Pengaruh suhu dan kecepatan ulir ekstruder terhadap cooking loss mi jagung

Hasil ini sejalan dengan penelitian Wang et al. (2012) yang menyatakan bahwa peningkatan suhu barrel ekstruder dapat 
menurunkan cooking loss mi pati. Lebih lanjut Wang et al. (2012) menyebutkan bahwa cooking loss tergantung pada gelatinisasi permukaan mi. Gelatinisasi semakin sempurna, amilosa semakin banyak yang lepas dari granula pati. Semakin banyak ikatan hidrogen yang terbentuk antar polimer amilosa, maka struktur mi semakin kokoh. Cooking loss meningkat dengan menurunnya suhu ekstruder, dimana suhu ekstruder yang rendah menyebabkan gelatinisasi tidak sempurna. Kecepatan ulir ekstruder tidak mempengaruhi cooking loss karena semakin cepat putaran ulir, semakin singkat adonan (residence time) melewati ekstruder, walaupun shear rate meningkat. Menurut Seker (2005) residence time yang singkat mempengaruhi kehomogenan adonan dalam proses ekstrusi dan berpengaruh terhadap tingkat pencampuran (degree of mixing).

Persen elongasi menunjukkan pertambahan panjang maksimum mi yang mengalami tarikan sebelum putus. Elongasi dinyatakan dalam satuan persen (\%). Mi dengan persen elongasi tinggi menunjukkan karakteristik mi yang tidak mudah putus. Sifat ini penting karena konsumen tidak menginginkan mi yang hancur saat dimasak atau putus ketika ditarik pada saat dikonsumsi. Pengaruh suhu ekstruder dan kecepatan ekstruder terhadap elongasi mi disajikan pada Gambar 3.

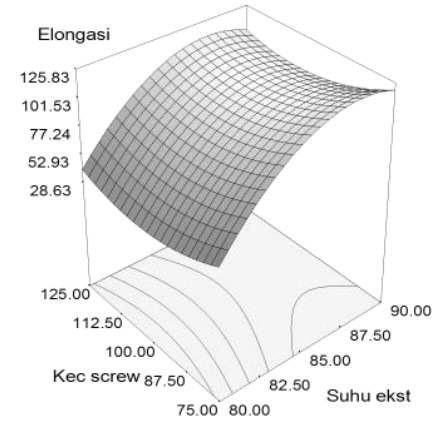

Gambar 3. Pengaruh suhu dan kecepatan ulir ekstruder terhadap elongasi mi jagung

Berdasarkan Tabel 2, peningkatan suhu ekstruder berpengaruh nyata terhadapel ongasimi kering jagung $(p<0,05)$. Kecepatan ulir ekstruder tidak berpengaruh nyata terhadap elongasimi kering jagung $(p>0,05)$. Peningkatan kecepatan ulir meningkatkan shear rate, tetapi juga menurunkan waktu tinggal (residence time) sehingga tidak meningkatkan gelatinisasi secara nyata, karena itu tidak meningkatkan elongasi mi yang dihasilkan.

Elongasi mi jagung semakin tinggi dengan peningkatan suhu ekstruder. Suhu ekstruder yang tinggi menyebabkan gelatinisasi semakin meningkat, dimana amilosa keluar dari pati dan akan membentuk struktur yang kompak ketika retrogradasi. Hal ini sesuai dengan Marti et al. (2011) menyatakan bahwa selama proses extrusion-cooking pasta, suhu tinggi dan shear stress menyebabkan terjadinya gelatinisasi dan pemecahan granula pati. Setelah retrogradasi, polimer pati akan berikatan ulang dan menghasilkan struktur matrik yang baru. Hal ini menunjukkan kecukupan gelatinisasi sangat menentukan sifat elongasi mi. Ketegaran mi (sering disebut juga sebagai kekerasan mi) adalah gaya yang diperlukan untuk menggigit mi sampai putus. Semakin tinggi ketegaran mi berarti semakin besar gaya yang diperlukan. Mi kering jagung yang telah direhidrasi diharapkan memiliki ketegaran yang tidak terlalu tinggi. Berdasarkan Tabel 2, suhu ekstruder dan kecepatan ulir ekstruder berpengaruh nyata pada ketegaran (kekerasan) mi jagung $(p<0,05)$. Peningkatan suhu ekstruder dapat meningkatkan ketegaran (kekerasan) mi jagung, karena semakin tinggi suhu ekstruder, tingkat gelatinisasi adonan tepung jagung semakin meningkat (Gambar 4). Menurut Wang et al. (2012) semakin tinggi tingkat gelatinisasi, semakin banyak amilosa yang keluar dari granula pati dan menyebabkan viskositas yang semakin tinggi ketika retrogradasi.

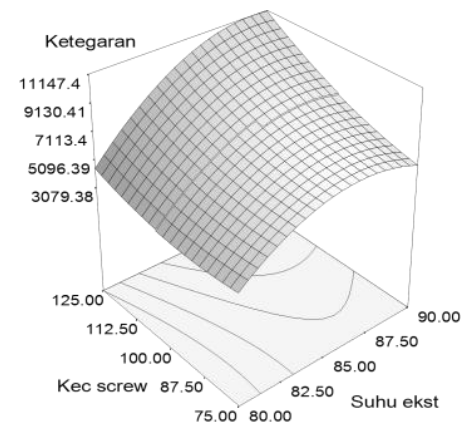

Gambar 4. Pengaruh suhu dan kecepatan ulir ekstruder terhadap ketegaran mi jagung

Peningkatan kecepatan ulir meningkatkan ketegaran mi jagung. Fenomena pengaruh kecepatan ulir terhadap ketegaran mi ternyata berbeda dengan fenomena pada elongasi dan cooking loss mi. Ketegaran mi tidak hanya dipengaruhi oleh efek gelatinisasi, tetapi juga dipengaruhi oleh perubahan mikrostruktur mi akibat perlakuan kecepatan ulir ekstruder, meskipun jumlah pati yang tergelatinisasi tidak berbeda. Pada jumlah air yang digunakan dalam penelitian ini $(80 \% \mathrm{bb})$ semakin tinggi kecepatan ulir, kompresi semakin meningkat sehingga kepadatan adonan mi semakin tinggi. Pada saat pemasakan, semakin kecil penetrasi air dan panas ke dalam mi, sehingga kekerasan mi meningkat. Kekenyalan adalah kemampuan mi untuk kembali ke bentuk semula setelah mendapat gaya tekan. Berdasarkan Tabel 2, kekenyalan dipengaruhi secara nyata oleh suhu ekstruder $(p<0,05)$ dan tidak dipengaruhi oleh kecepatan ulir ekstruder $(p>0,05)$. Semakin tinggi suhu ekstruder, kekenyalan mi jagung semakin besar (Gambar 5).

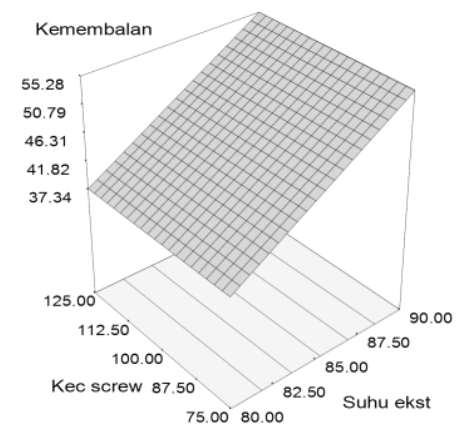


Gambar 5. Pengaruh suhu dan kecepatan ulir ekstruder terhadap kekenyalan mi jagung

Menurut Marti et al. (2011) kekokohan struktur ini dipengaruhi oleh tingkat gelatinisasi granula pati atau tepung. Semakin tinggi suhu ekstruder, semakin tinggi pula tingkat gelatinisasi dan mi yang dihasilkan memiliki tingkat kekenyalan yang semakin tinggi.

Kelengketan merupakan daya rekat yang ditunjukkan dengan besarnya gaya yang dibutuhkan untuk menarik bagian pangan dan memisahkannya dari lempeng kompresi. Mi yang dihasilkan diharapkan memiliki nilai kelengketan yang rendah agar memiliki eating quality yang baik. Seperti terlihat pada Tabel 2, peningkatan suhu ekstruder berpengaruh nyata terhadap kelengketan $(p<0,05)$, sedangkan kecepatan ulir tidak berpengaruh nyata $(p<0,05)$. Semakin tinggi suhu, semakin rendah kelengketan mi (Gambar 6).

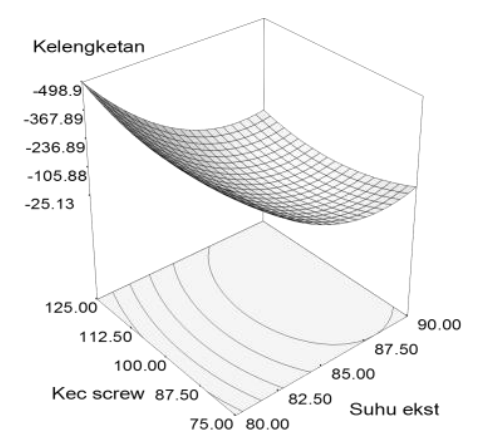

Gambar 6. Pengaruh suhu dan kecepatan ulir ekstruder terhadap kelengketan mi jagung

Menurut Marti et al. (2010) semakin tinggi tingkat gelatinisasi, semakin banyak amilosa yang keluar dari granula pati, ikatan hidrogen antar amilosa semakin terbentuk (ketika retrogradasi) dan menurunkan kelengketan mi. Semakin tinggi suhu ekstruder, tingkat gelatinisasi semakin tinggi. Ikatan hidrogen antar amilosa terbentuk secara sempurna, sehingga amilosa pada permukaan mi tidak mudah lepas ketika mi dimasak, yang berdampak pada penurunan kelengketan. Fenomena pengaruh gelatinisasi pada kelengketan mi sejalan dengan fenomena pada cooking loss.

\section{Proses optimum pembuatan mi jagung dengan metode RSM}

Mi basah jagung yang dihasilkan dari ekstruder pemasapencetak memiliki tingkat kekerasan yang sangat tinggi dibandingkan dengan kekerasan mi terigu (Muhandri et al., 2011). Oleh karena itu, proses yang optimum ditetapkan dengan dasar sebagai berikut: (1) ketegaran (kekerasan) dan cooking loss adalah minimum, (2) elongasi, kekenyalan dan kelengketan adalah in range. Pembatas (constraint) dan tingkat kepentingan dalam penetapan proses optimum disajikan pada Tabel 3; sedangkan solusi yang dipilih disajikan pada Tabel 4 . Tingkat kepentingan ditetapkan dengan bobot yang sama yaitu 3 atau moderat (dari skala 1-5).

Pada kadar air adonan yang telah ditetapkan yaitu $80 \%$ (berat tepung), proses optimum diperoleh pada suhu ekstruder $90^{\circ} \mathrm{C}$ dan kecepatan ulir ekstruder $75 \mathrm{rpm}$. Kondisi proses yang optimum ini berbeda dengan yang diperoleh pada penelitian sebelumnya (Muhandri et al., 2011). Hal ini disebabkan perbedaan tipe die ekstruder yang digunakan. Muhandri et al. (2011) menggunakan die yang berbentuk bulat dengan diameter 2,5 $\mathrm{mm}$ dan berjumlah 2 buah, sedangkan penelitian ini menggunakan die berbentuk elips dengan ukuran $1 \times 1,5 \mathrm{~mm}$ yang berjumlah 9 buah.

Mi kering jagung pada proses optimum ini memiliki penampakan yang bersifat glossy (mengkilap seperti kaca). Penampakan seperti ini kurang disukai oleh panelis (Gambar 7.a.). Meskipun, ketika dimasak (direhidrasi) penampakan mi cukup bagus (Gambar 7.b.). Selain itu, mi jagung yang telah direhidrasi masih memiliki tingkat kekerasan yang tinggi yaitu 5897,75 gf jika dibandingkan dengan mi terigu hasil penelitian Muhandri et al. (2011) yaitu sebesar 987,70 gf.

Tabel 3. Pembatas (constraint) pada penetapan proses optimum dengan RSM

\begin{tabular}{lcccc}
\hline \multicolumn{1}{c}{ Parameter } & Tujuan & Batas Bawah & Batas Atas & $\begin{array}{c}\text { Tingkat } \\
\text { Kepentingan }\end{array}$ \\
\hline Suhu & In range & 80 & 90 & 3 \\
Kecepatan & In range & 75 & 125 & 3 \\
ulir & & & & \\
Cooking loss & Minimum & 4,31 & 13,46 & 3 \\
Elongasi & In range & 34,53 & 135,46 & 3 \\
Ketegaran & Minimum & 3207,2 & 11589,8 & 3 \\
Kekenyalan & In range & 35,55 & 60,43 & 3 \\
Kelengketan & In range & 41,3 & 542,1 & 3 \\
\hline
\end{tabular}
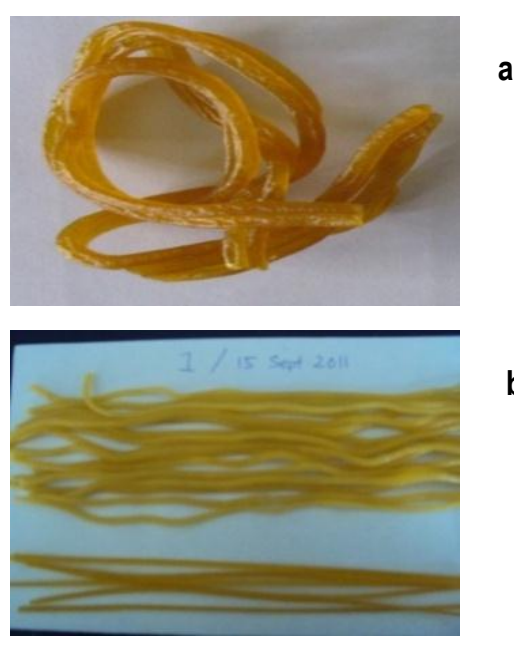

b

Gambar 7. Mi kering jagung (a) sebelum rehidrasi, (b) setelah direhidrasi

Tabel 4. Nilai desirability pada berbagai kondisi proses yang optimum

\begin{tabular}{ccccccc}
\hline Suhu $\left({ }^{\circ} \mathrm{C}\right)$ & $\begin{array}{c}\text { Kecepatan Ulir } \\
(\mathrm{rpm})\end{array}$ & Cooking loss (\%) & Elongasi (\%) & Ketegaran (gf) & Kemembalan (\%) & Kelengketan (gf) \\
\hline 90,00 & 75,00 & 4,80 & 120,00 & 5897,75 & 55,17 & 90,07
\end{tabular}



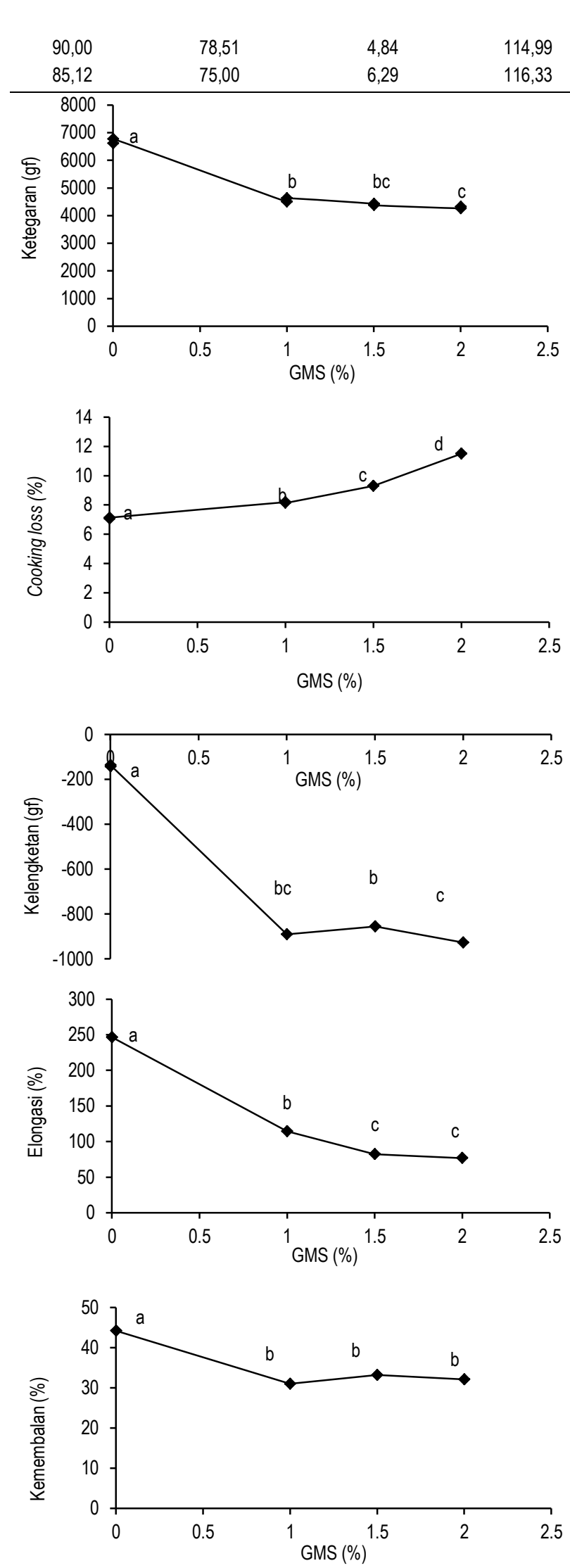

Keterangan :Huruf yang berbeda menunjukkan perbedaan yang nyata pada $p<0,05$

$\begin{array}{llll}6083,20 & 55,18 & 67,61 & 0,787 \\ 6643,71 & 46,46 & 108,91 & 0,680\end{array}$

Gambar 8. Pengaruh penambahan GMS terhadap karakteristik mi kering jagung yang telah direhidrasi (direbus selama 8 menit)

\section{Pengaruh penambahan GMS (Gliseril Mono Stearat)}

Berdasarkan hasil analisis ragam (ANOVA) dan uji lanjut Duncan, penambahan GMS 1\% (dari berat tepung) ternyata mampu secara signifikan $(p<0,05)$ menurunkan ketegaran, elongasi dan kekenyalan mi kering jagung yang telah direhidrasi; serta meningkatkan cooking loss dan kelengketan mi jagung. Namun penambahan pada jumlah yang lebih tinggi tidak berpengaruh nyata terhadap mi jagung (Gambar 8). Penambahan GMS lebih tinggi lagi mengakibatkan tingginya cooking loss mi kering jagung.

Menurut Charutigon et al. (2008) kemampuan mono gliserida (GMS) membentuk kompleks (tidak larut air) dengan amilosa, mampu mencegah pelepasan amilosa selama proses gelatinisasi, menghambat pengembangan granula dan menurunkan kemampuan pati dalam mengikat air. Hal ini menyebabkan penurunan ketegaran, elongasi, kekenyalan dan kelengketan mi, tetapi menyebabkan peningkatan cooking loss ketika mi jagung dimasak. Hal yang mirip disampaikan oleh Kaur et al. (2005) bahwa penambahan GMS dapat mencegah pelepasan amilosa dari granula pati. Lapisan kompleks tidak larut kemungkinan terbentuk di permukaan granula pati dan menghambat masuknya air ke dalam granula pati (Richardson et al., 2003).

\section{Karakteristik mi kering jagung terbaik}

Kelemahan mi pada tahap sebelumnya adalah tingkat kekerasan yang tinggi. Penambahan GMS 1\% b.k (dari berat tepung) sudah cukup untuk menurunkan secara nyata $(p<0,05)$ kekerasan mi jagung yang telah direhidrasi. Mi jagung yang diproses pada suhu $90^{\circ} \mathrm{C}$ dan kecepatan ulir ekstruder $75 \mathrm{rpm}$ dengan penambahan GMS sebanyak 1\% (dari berat tepung) merupakan proses terbaik (Gambar 9). Meskipun cooking loss meningkat dengan penambahan GMS $1 \%$, tetapi nilai cooking loss tersebut $(8,16 \%)$ masih cukup bagus. Menurut Charutigon et al. (2008) cooking loss di bawah 12,5\% dapat diterima oleh konsumen.
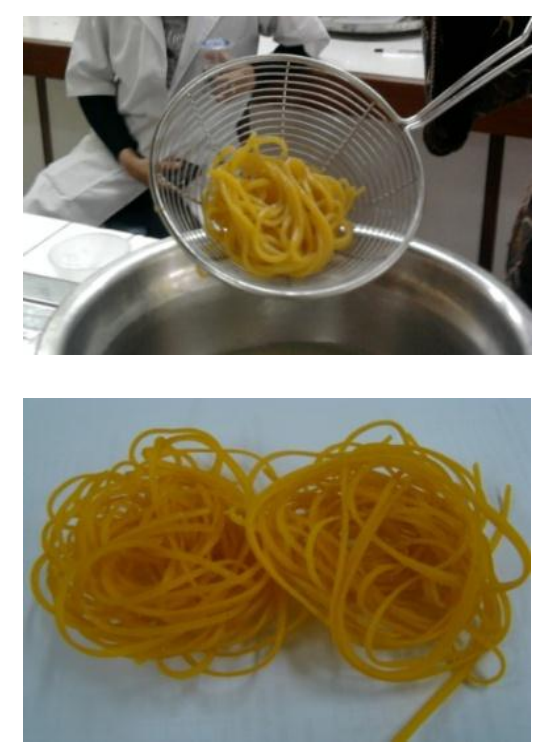
Gambar 9. Mi kering jagung pada kondisi proses optimum (a) sebelum rehidrasi, (b) sesudah rehidrasi

Preferensi panelis terhadap atribut mutu mi jagung

Sampel yang diuji adalah mi hasil proses optimum. Berdasarkan hasil pengukuran secara obyektif, mi tersebut memiliki elongasi $112,36 \%$, ketegaran 6872,20 gf, dan kekenyalan $60,43 \%$. Frekuensi panelis yang menyatakan nilai untuk setiap atribut mutu mi jagung disajikan pada Tabel 5.

Tabel 5. Persentase panelis $(n=30)$ dalam penilaian atribut mutu mi jagung

\begin{tabular}{lccccc}
\hline \multirow{2}{*}{\multicolumn{1}{c}{ Atribut Mutu Mi }} & \multicolumn{5}{c}{ Persentase Menurut Skor (\%) } \\
\cline { 2 - 6 } & 1 & 2 & 3 & 4 & 5 \\
\hline Elongasi & 0 & 0 & 23 & 60 & 17 \\
Ketegaran & 7 & 10 & 20 & 63 & 0 \\
Kekenyalan & 0 & 30 & 23 & 47 & 0 \\
Penampakan umum & 0 & 17 & 10 & 70 & 3 \\
\hline
\end{tabular}

Berdasarkan hasil analisis tersebut, mi kering jagung yang telah direbus selama 8 menit memiliki penampakan umum yang dianggap baik oleh banyak panelis (70\% panelis memberikan skor 4). Untuk setiap atribut mutu mi, $60 \%$ panelis memberikan skor 4 untuk elongasi, 63\% panelis memberikan skor 4 untuk ketegaran, dan $47 \%$ panelis memberikan skor 4 untuk kekenyalan.

\section{KESIMPULAN DAN SARAN}

\section{Kesimpulan}

Kondisi proses optimum pembuatan mi jagung pada kondisi kadar air $80 \%$ (basis berat basah tepung) dengan menggunakan RSM adalah suhu $90^{\circ} \mathrm{C}$ dan kecepatan ulir ekstruder $75 \mathrm{rpm}$. Penambahan GMS dapat memperbaiki karakteristik pencetakan. Selain itu, juga memperbaiki karakteristik mi kering jagung yang telah direhidrasi, yaitu menurunkan kekerasan dan elongasi. Berdasarkan hasil uji preferensi diketahui bahwa mi jagung yang telah direhidrasi memiliki elongasi, ketegaran, kekenyalan, dan penampakan umum yang disukai panelis.

\section{Saran}

Perlu dilakukan penelitian lebih lanjut tentang pengaruh suhu pengeringan terhadap karakteristik mi kering jagung. Selain itu, perlu juga mengetahui pengaruh penyimpanan mi kering jagung terhadap karakateristik mi yang direhidrasi.

\section{DAFTAR PUSTAKA}

Charutigon C, Jitpupakdree J, Namsree P, Rungsardthong V. 2008. Effects of processing conditions and the use of modified starch and monoglyseride on some properties of extruded rice vermicelli. LWT Food Sci Technol 41: 642651. DOI: 10.1016/j.Iwt.2007.04.009.

Inazu T, Iwasaki KI, Furuta T. 2002. Effect of temperature and relative humidity on drying kinetics of fresh japanese noodle (udon). LWT Food Sci Technol 35: 649-655. DOl: 10.1006/fstl.2002.0921.

Henika RG. 1982. Use of response-surface methodology in sensory evaluation. Food Tech 9: 91-101.

Kaur L, Singh J, Singh N. 2005. Effect of glycerol monostearate on the physico-chemical, thermal, rheological and noodle making properties of corn and potato starches. Food Hydrocoll 19: 839-849. DOI: 10.1016/j.foodhyd.2004. 10.036.

Marti A, Seetharaman K, Pagani MA. 2010. Rice-based pasta: A comparison between conventional pasta-making and extrusion-cooking. J Cereal Sci 52: 404-409. DOI: 10.1016/j. ics.2010.07.002.

Marti A, Pagani MA, Seetharaman K. 2011. Understanding starch organization in gluten-free pasta from rice flour. Carbohyd Polym 84: 1069-1074. DOl: 10.1016/..carbpol.2010.12.070.

Muhandri T, Ahza AB, Syarief R, Sutrisno. 2011. Optimasi proses ekstrusi mi jagung dengan metode respon permukaan. J Teknol dan Industri Pangan 22: 97-104.

Richardson G, Langton M, Bark A, Hermansson AM. 2003. Wheat starch gelatinization the effects of sucrose, emulsifier and the physical state of the emulsifier. Starch-Starke 55: 150-161. DOl: 10.1002/star.200390029.

Seker M. 2005. Residence time distributions of starch with high moisture content in a single screw extruder. J Food Eng 67: 317-324. DOI: 10.1016/j.jfoodeng.2004.04.034.

Wang N, Maximiuk L, Toews R. 2012. Pea starch noodles: Effect of processing variables on characteristics and optimisation of twin-screw extrusion process. Food Chem 133: 742-753. DOI: 10.1016/j.foodchem.2012.01.087.

Waniska RD, Yi T, Lu J, Ping LX, Xu W, Lin H. 1999. Effects of preheating temperature, moisture, and sodium metabisulfite content on quality of noodles prepared from maize flour or meal. Food Sci Technol Int 5: 339-346. DOl: 10.1177/108201329900500406. 